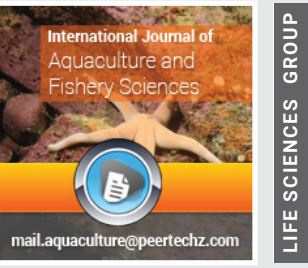

\title{
Effect of ginger (Zingiber officinale) in the nutrition of african catfish-A cholesterol reducer and fertility enhancer
}

Received: 01 April, 2020

Accepted: 11 May, 2020

Published: 12 May, 2020

*Corresponding author: Olaniyi CO, Department of Animal Production and Health, Ladoke Akintola University of Technology, Ogbomoso, Nigeria,

E-mail: oludayo.olaniyi@gmail.com; coolaniyi@lautech.edu.ng

Keywords: Clarias gariepinus; Zingiber officinale; Growth; Serum biochemical indices; Sperm and eggs https://www.peertechz.com

Check for updates

\section{Olaniyi CO*, Atoyebi MO, Obafunmiso HT and Salaam KA}

Department of Animal Production and Health, Ladoke Akintola University of Technology, Ogbomoso, Nigeria

\section{Abstract}

A twelve weeks nutritional study was carried out to study the effect Zingiber officinale on the growth performance, blood profiles, eggs and sperm quality of juvenile African catfish (Clarias gariepinus). in which juvenile African catfish (Clarias gariepinus) were fed Five diets containing $35 \% \mathrm{CP}$ were formulated having varying inclusion levels $(0,5,10,15$ and $20 \%$ ) of ginger (Zingiber officinale) for Diet 1, 2, 3, 4 and 5 respectively. One hundred (100) juvenile African catfish ( $94.24 \pm 0.02 \mathrm{~g}$ ) were randomly selected, divided into five dietary treatments and stocked at the rate of 10 juveniles per tank (120L) and replicated two times. The fish were fed add libitum twice daily and weight changes were recorded every two weeks. At the end of the feeding trials, blood samples were taken, the sperm and egg sacs were excised from the fish samples selected and the sperm and eggs were collected for analysis. Data collected on weight changes, feed-intake, blood parameters and sperm volume, percentage motility, sperm density, percentage livability and death percentage were subjected to one way analysis of variance (ANOVA) using Completely Randomized Design (CRD).

The results revealed that fish increased significantly in weight $(P<0.05)$ as the level of ginger inclusion increases in diets and utilized the feed efficiently than the control. Significant differences $(P<0.05)$ were observed in all the growth parameters. Treatment4 (fish fed $15 \%$ ginger based diet) had the highest mean weight gain (166.71g), percentage weight gain (176.90\%), specific growth rate (0.54\%), protein efficiency ratio (1.64) and red blood cells (3.86cmm). Also, fish fed $15 \%$ ginger based diet (T4) recorded least alkaline phosphate (13.62u/l), alanine transaminase (67.73otu/l), ALT (22.36u/l) and Creatinine (0.18mg/dl). However, fish fed $20 \%$ ginger based diet (T5) had higher sperm motility (67.50\%), sperm livability (180.85\%), egg volume (40ml), egg weight(36.50g) and egg number (25600) while the least sperm motility and livability $(45.00 \%, 92.05 \%)$ respectively were obtained in T4. Although, the least values of egg volume, weight and number (25ml, $24 \mathrm{~g}$, 16500$)$ respectively were recorded in control (T1).

Therefore, it can be concluded that $15 \%$ ginger can be included in the diet of African catfish (Clarias gariepinus) to enhance growth, good heamatological and reduced antinutrients although, greater success were recorded for reproductive performance using higher level of ginger(20\%) without detrimental effect.

\section{Introduction}

The African catfish (Clarias gariepnus) [1], is a species of catfish of the family Clariidae and is an important fish species in both aquaculture and capture fisheries [2]. It contributes $22 \%$ of animal protein in sub-saharan Africa and $40 \%$ of animal protein for consumption in Nigeria [3]. In Africa, this catfish has been reported to be the biggest in size in terms of length and weight and popularly cultivated species [4]. In Nigeria, Catfish culture started from inception with aquaculture and is majorly the only hope of fish supply sustainability. Recently all over the world, there is a decline in landing from capture fisheries which is an indication that fish stocks have exceeded the point of maximum sustainable yield. Apart from Tilapia, African catfish belonging to the family of Claridae is the most commonly cultivated fish in Nigeria. The steady rise in catfish culture has greatly boosted aquaculture growth in Nigeria. However, the problem of inadequate availability of stock has hampering its production. Although, induced breeding (hypophysation) has been introduced and widely used throughout Nigeria to increase the production of farmraised catfish [5]. Currently, natural materials (medicinal plants) such as bitter leaf, scent leaf, bitter kola have been widely accepted as feed additives to enhance feed utilization and aquaculture productive, performance and sustainability [6]. Phytogenic feed additives, also known as phytobiotics 
products are plant derived products, used in animal feeding to improve performance through amelioration of feed properties, promotion of production performance and improving the quality of animal origin food/feed [7]. Also, ginger being a natural and readily available additive could be used as fertility booster in fish which might also be a possible solution to the inadequacies of fingerlings supply, hence increasing the African catfish market in Nigeria.

Ginger is a flowering plant whose rhizome is commonly used as spice and flavouring agent. It is cultivated nationwide [8]. Ginger is a spice and medicinal plant that has been used in the pharmaceutical, food and chemical industries. It contains ant- oxidative and androgenic activities which has used in diseases treatment in many countries worldwide [9], Ginger and its constituents have antiemetic, antithrombotic, antihepatotoxic, anti inflammatory, stimulant, cholagogue. Androgenic and antioxidant properties. As antioxidants it protect DNA and other important molecules from oxidation and damage, and can improve sperm quality and consequently increase fertility rate in men [10]. Ginger, boost metabolism, immune systems as well as effective in decreasing sperm DNA fragmentation (SDF) in infertile men [11].

A study has revealed that inclusion of ginger root powder in laying hens diet increased their egg production and weight compared with control laying hens [12]. It was also reported that, ginger roots essential oil significantly increased the relative uterus weight, egg weight, fertility and hatchability rates in the female quail compared to the control birds. In fish, ginger has been successfully used to control an Aeromonas hydrophila infection in rainbow trout [13]. In addition, ginger has been used as immune-modulatory agent in animals and fish to reduce the losses caused by diseases in aquaculture $[13,14]$.

These studies therefore, investigate the effect of ginger in the nutrition, blood profile and reproduction of African catfish.

\section{Materials and methods}

\section{Experimental site}

This experiment was conducted at the fishery unit of Teaching and Research Farm, Ladoke Akintola University of (LAUTECH), Ogbomoso, Oyo state Nigeria.

\section{Processing of ginger (test ingredient)}

The dried ginger was obtained from a local market in Ogbomoso. The ginger were sun dried to a constant weight, ground to fine powder and stored in an air tight container prior the use for the experiment.

\section{Experimental diets}

The ingredients such as maize, wheat offal, GNC, soybean, fish meal, oyster shell, bone meal, premix, lysine, salt and vegetable oil were procured from a reputable feed mill in ogbomoso. Five isonitrogenous $(35 \% \mathrm{CP})$ diets were formulated in which diet 1 contained ( $0 \%$ ginger), diet $2(5 \%$ ginger), diet 3
(10\% ginger), diet 4 (15\% ginger) and diet 5 (20\% ginger).The ingredients were mixed thoroughly with varying percentage of ginger and then pelletized to reduce dustiness for proper and easy acceptance by the juvenile. The pellets were sundried to constant weight and packed into air tight sack and stored for use.

\section{Experimental fish}

Two hundred (200) juvenile African catfish were obtained from a reputable farm in ogbomoso and acclimatized for the period of two weeks after which, one hundred (100) juvenile African catfish $(94.24 \pm 0.02 \mathrm{~g})$ were randomly selected and divided into five (5) dietary treatments. The fish were stocked at the rate of 10 juveniles (4male: 6 females) per tank (120L) and replicated two times (due to the number of fish within the weight ranges selected for the study). The water used was exposed for three days to allow oxygen dissolution into the water. The waste and faeces in all the tanks were siphoned every day to prevent pollution.

\section{Feeding and weighing}

The fishes were fed experimental diet (add libitum) twice daily, both in the morning and evening (8:0ohrs and 16:0ohrs). Fishes were weighed every two weeks for the period of twelve weeks using an electronic digital weighing balance, the record of the feed consumption was also taken.

\section{Data collection}

Data such as fish weight and feed intake were collected during the feeding trial and the following parameters - Mean weight gain (MWG), Percentage weight gain (PWG), Specific growth rate (SGR), Feed conversion rate (FCR), Protein intake (PI), Protein efficiency ratio (PER) were calculated

Mean Weight Gain $($ MWG $)=$ Final weight $(\mathrm{g})-$ Initial weight gain $(\mathrm{g})$.

Average Daily Weight Gain (ADWG)g/day = Mean Weight Gain (g) / Length of feeding trial (days)

Percentage Weight Gain (PWG)\% = Mean Weight Gain/ Initial mean weight $(\mathrm{g}) \mathrm{x} 100$

Specific Growth Rate( SGR) = Log $\mathrm{W}_{2-} \log \mathrm{W}_{1} / \mathrm{T}_{2}-\mathrm{T}_{1} \times 100$

$\mathrm{W}_{1}$ = initial weight $(\mathrm{g}), \mathrm{W}_{2}$ = final weight $(\mathrm{g}), \mathrm{Log}$ = natural $\log$ to base

$\mathrm{T}_{2}-\mathrm{T}_{1}=$ time interval between initial and final weight (days)

Feed Conversion Ratio $($ FCR $)=$ Feed intake $/$ Net weight gain

Protein Efficiency Ratio (PER) = Net weight gain/ Amount of protein fed

\section{Blood sample collection}

Blood samples for haematology and serum analysis were collected at the end of the feeding trial from the caudal penducle of both the test and control fishes with new $2 \mathrm{ml}$ syringe. The 
blood samples were dispensed into a tube containing Ethylene diamine tetra acetate (EDTA) to avoid clotting of the blood sample and Eppendorf tubes for serum samples preparation. The samples were preserved with ice cubes and taken to the laboratory for analysis.

\section{Milts and eggs collection}

Three male and female fishes were randomly selected from all the treatments for milt and egg collection. The fishes were deoxidized and the testes excised and eggs were siphoned from the female ovum with the use of hose. After which the sperm and eggs were viewed under the computer microscope.

\section{Milt count}

Concentration of sperm will be determined by counting the numbers of spermatozoa in sample dilute with distilled water (100x) in a Burkerhaemocytometer under 400x magnigication.

\section{Percentage motility}

Each sample were estimated using large microscope at 400x magnification, immediately after addition of $20 \mathrm{ul}$ distilled water as an activating solution. During spermatozoa activation, immotile sperm cell (ISC) was counted, when the activation stopped, whole sperm cell (WSC) as counted, motile sperm cell (MC) was calculated.

MC $=$ WSC - ISC

MC\%- MC/WSC $\times 100$

\section{Milt and egg analysis}

The milt was analyzed with the use of a computer aided system and the data were, mathematically elaborated to obtain numerical indices expressing the statue of the ejaculation and egg production. The eggs were analysed to determine the volume, weight, colour and number of eggs.

\section{Chemical analysis}

Proximate composition of test ingredient (ginger), fish sample and experimental diets were determined according to the methods of Association of analytical chemist [15].

\section{Statistical analysis}

All data collected during experimental period were subjected to a one-way analysis of variance (ANOVA) using completely randomized design in accordance with SPSS and Duncan's multiple range tests was employed to reveal significant differences among the means.

\section{Results}

The gross composition of experimental diets is as shown in Table 1and it revealed all the ingredients used for the five diets formulated for the experiment. The proximate composition of ginger (ZingiberOfficinale) in Table 2 were as follows : crude protein $8.75 \%$, crude fibre $9.2 \%$, ether extract $4.6 \%$, moisture $6.6 \%$ and ash $6.2 \%$.
The proximate composition of the experimental diets is as shown in Table 3. All the diets had averagely $34.75 \%$ crude protein, $5.09 \%$ crude fibre, $6.80 \%$, ether extract, $7.69 \%$ ash, $43.23 \%$ nitrogen free extract.

The growth performance and nutrient utilization of juvenile African catfish fed ginger based diets was revealed in Table 4. Highest FMW, MWG,ADWG, PWG, SGR, AFI, PI and PER (260.95g, 166.71g, 1.99g, 176.90\%, 0.54, 290.56g, 101.71g, and 1.64 ) were obtained in treatment 4 (15\%ginger) while the least FMW, MWG,ADWG, PWG, SGR and PER (212.15g, 117.91g, 1.40g, $125.12 \% 0.43 \%, 1.40 \%)$ were recorded in treatment $5(20 \%$ ginger) respectively. Although, the least AFI (224.96g) and PI (78.74) were obtained in $\mathrm{T} 1$ (Control). Also, the least value of FCR (1.74) was obtained at treatment 4 (15\% ginger) while the highest FCR (2.04) was found with treatment 5.

The carcass composition of juvenile African catfish fed ginger meal was recorded in Table 5. T3 having the highest $\mathrm{CP}$ (51.84\%) while $\mathrm{T} 5$ has the least $\mathrm{CP}$ value $(47.25 \%)$, T3 has the highest CF $(9.00 \%)$ and the least was recorded in $\mathrm{T} 1 \mathrm{(7.41 \% )}$ and the values of other treatments $(\mathrm{T} 2, \mathrm{~T} 4, \mathrm{~T} 5)$ are closely related having values $(8.80,8.20$ and $8.82 \%$ ) respectively. Ether extract is highest (21.01\%) in $\mathrm{T}_{5}$ and lowest (15.24\%) in $\mathrm{T} 4$, moisture content of $\mathrm{T} 2$ is the highest $(9.01 \%)$ while the highest was recorded in $\mathrm{T} 4(2.24 \%)$. $\mathrm{T} 4$ has the highest ash and

Table 1: Gross Composition of the Experimental Diets.

\begin{tabular}{|c|c|c|c|c|c|}
\hline Ingredients & $\mathrm{T}_{\mathbf{1}} \mathbf{( 0 \% )}$ & $\mathrm{T}_{\mathbf{2}} \mathbf{( 5 \% )}$ & $\mathrm{T}_{\mathbf{3}} \mathbf{( 1 0 \% )}$ & $\mathrm{T}_{\mathbf{4}} \mathbf{( 1 5 \% )}$ & $\mathrm{T}_{\mathbf{4}} \mathbf{( 2 0 \% )}$ \\
\hline Maize & 20.60 & 20.60 & 20.60 & 20.60 & 20.60 \\
\hline Wheat offal & 10.30 & 10.30 & 10.30 & 10.30 & 10.30 \\
\hline GNC & 22.20 & 22.20 & 22.20 & 22.20 & 22.20 \\
\hline Soybean & 33.30 & 33.30 & 33.30 & 33.30 & 33.30 \\
\hline Fish meal & 11.10 & 11.10 & 11.10 & 11.10 & 11.10 \\
\hline Ginger & - & 0.02 & 0.04 & 0.06 & 0.08 \\
\hline Oyster shell & 0.50 & 0.50 & 0.50 & 0.50 & 0.50 \\
\hline Bone meal & 0.50 & 0.50 & 0.50 & 0.50 & 0.50 \\
\hline Premix & 0.50 & 0.50 & 0.50 & 0.50 & 0.50 \\
\hline Lysine & 0.50 & 0.50 & 0.50 & 0.50 & 0.50 \\
\hline Salt & 0.25 & 0.25 & 0.25 & 0.25 & 0.25 \\
\hline Vegetable oil & 0.25 & 0.25 & 0.25 & 0.25 & 0.25 \\
\hline Total & 100 & 100 & 100 & 100 & 100 \\
\hline
\end{tabular}

Table 2: Proximate Composition of Test Ingredient (Ginger).

\begin{tabular}{|l|l|l|l|l|l|} 
Ingredient & Crude Protein & Crude Fibre & Ether Extract & Moisture & Ash \\
\hline
\end{tabular}

\begin{tabular}{|c|c|c|c|c|}
\hline Ginger & $8.75 \%$ & $9.20 \%$ & $4.60 \%$ & $6.60 \%$ \\
\hline
\end{tabular}

Table 3: Proximate Composition of Experimental Diets.

\begin{tabular}{|r|r|r|r|r|c|c|}
\hline & CP(\%) & CF (\%) & EE (\%) & Ash(\%) & Moisture (\%) & NFE (\%) \\
\hline T1 & 34.75 & 5.20 & 6.20 & 7.62 & 6.60 & 39.63 \\
\hline T2 & 34.76 & 6.02 & 5.40 & 7.60 & 6.62 & 39.60 \\
\hline T3 & 34.75 & 4.01 & 6.60 & 6.80 & 6.71 & 41.13 \\
\hline T4 & 34.75 & 6.80 & 5.20 & 7.81 & 6.61 & 38.83 \\
\hline T5 & 34.72 & 3.41 & 10.60 & 8.60 & 6.62 & 36.05 \\
\hline
\end{tabular}

Citation: Olaniyi CO, Atoyebi MO, Obafunmiso HT, Salaam KA (2020) Effect of ginger (Zingiber officinale) in the nutrition of african catfish-A cholesterol reducer and fertility enhancer. Int J Aquac Fish Sci 6(2): 021-028. DOI: https://dx.doi.org/10.17352/2455-8400.000052 
NFE value (13.01and 9.66\%) respectively, ash content (7.45\%) is low in $\mathrm{T} 1$ while NFE is lowest (5.99\%) in $\mathrm{T} 2$.

\section{Haematology and serum}

Haematology of the experimental fish is presented in Table 6. Highest PCV ( $48 \%$ ) was discovered in treatments five (T5) while the lowest PCV value $(40 \%)$ was found with $\mathrm{T} 2$ Treatment one (T1) has the highest WBC $(12.00 \mathrm{cmm})$ while treatment four (T4) has the least value $(7.60 \mathrm{cmm})$. Treatment two (T2) was discovered to have the highest $(37.50 \%)$ heterophil while treatment five ( $\left.\mathrm{T}_{5}\right)$ has the least $(25.00 \%)$ value. Highest values of lymphocytes $(52.50 \%)$ and neutrophils $(3.50 \%)$, were observed in treatment four $\left(\mathrm{T}_{4}\right)$ and five $\left(\mathrm{T}_{5}\right)$ respectively, while the least values $(29.00 \%)$ and $(1.00 \%)$ were observed in treatments one (T1) and three (T3) respectively. There was a noticeable difference in the basophil value among the treatments with treatment one (T1) having the highest value $(20.00 \%)$ and treatment two $(\mathrm{T} 2)$ having the least value $(8.50 \%)$.

The findings of the present study on the haematology revealed that Clarias gariepinus juvenile fed with ginger meal

Table 4: Growth Performance and Nutrient Utilization of Juvenile African catfish fed Varying Levels of Ginger Meal.

\begin{tabular}{|c|c|c|c|c|c|c|}
\hline PARAMETER & T1(control) & T2 (5\%) & T3(10\%) & T4(15\%) & T5 (20\%) & SEM \\
\hline SURVIVAL RATE (\%) & 100 & 100 & 100 & 100 & 100 & \\
\hline IMW(g) & 94.24 & 94.24 & 94.24 & 94.24 & 94.24 & 0.01 \\
\hline FMW & $216.45^{\mathrm{d}}$ & $249.4^{\mathrm{b}}$ & $245.85^{\mathrm{c}}$ & $260.95^{\mathrm{a}}$ & $212.15^{\mathrm{e}}$ & 3.56 \\
\hline MWG & $122.4^{\mathrm{d}}$ & $155.01^{\mathrm{b}}$ & $151.61^{\mathrm{c}}$ & $166.71^{\mathrm{a}}$ & $117.91^{\mathrm{e}}$ & 3.56 \\
\hline ADWG & $1.46^{\mathrm{c}}$ & $1.85^{\mathrm{b}}$ & $1.81^{\mathrm{b}}$ & $1.99^{\mathrm{a}}$ & $1.40^{\mathrm{c}}$ & 0.04 \\
\hline PWG & $129.68^{\mathrm{d}}$ & $164.48^{\mathrm{b}}$ & $160.88^{\mathrm{c}}$ & $176.90^{\mathrm{a}}$ & $125.12^{\mathrm{e}}$ & 3.78 \\
\hline SGR & $0.44^{\mathrm{bc}}$ & $0.51^{\mathrm{a}}$ & $0.50^{\mathrm{ab}}$ & $0.54^{\mathrm{a}}$ & $0.43^{\mathrm{c}}$ & 0.01 \\
\hline AFI & $224.96^{\mathrm{e}}$ & $284.77^{\mathrm{b}}$ & $275.47^{\mathrm{c}}$ & $290.56^{\mathrm{a}}$ & $240.57^{\mathrm{d}}$ & 4.80 \\
\hline FCR & $1.84^{\mathrm{b}}$ & $1.84^{\mathrm{b}}$ & $1.82^{\mathrm{b}}$ & $1.74^{\mathrm{c}}$ & $2.04^{\mathrm{a}}$ & 0.02 \\
\hline PI & $78.74^{\mathrm{e}}$ & $99.67^{\mathrm{b}}$ & $96.42^{\mathrm{c}}$ & $101.71^{\mathrm{a}}$ & $84.20^{\mathrm{d}}$ & 1.68 \\
\hline PER & $1.55^{\mathrm{b}}$ & $1.56^{\mathrm{b}}$ & $1.57^{\mathrm{b}}$ & $1.64^{\mathrm{a}}$ & $1.40^{\mathrm{c}}$ & 0.02 \\
\hline
\end{tabular}

$a, b, c, d$ and e superscripts. Means with the same superscript in the same row are not significantly different $(P>0.05)$

IW: Initial Weight; TFT: Total Feed Taken; ADVG: Average Daily Weight Gain; FW: Final Weight; AFI: Average Feed Intake; SGR: Specific Growth Rate; IMW: Initial Mean Weight; WG: Weight Gain; PI: Protein Intake; FMW: Final Mean Weight; FCR: Feed Conversion Ratio; PER: Protein Efficiency Ratio; MWG: Mean Weight Gain; PWG: Percentage Weight Gain

Table 5: Carcass Composition of Juvenile African catfish fed Ginger Meal.

\begin{tabular}{|c|c|c|c|c|c|c|c|}
\hline Parameters & Initial & T1(control) & T2(5\%) & T3(10\%) & T4(15\%) & T5(20\%) & SEM \\
\hline Crude Protein & & $50.77^{c}$ & $48.13^{d}$ & $51.84^{\mathrm{a}}$ & $51.69^{b}$ & $47.25^{e}$ & 0.35 \\
\hline Crude Fibre & & $7.41^{d}$ & $8.80^{\mathrm{b}}$ & $9.00^{\mathrm{a}}$ & $8.20^{\mathrm{b}}$ & $8.82^{b}$ & 0.11 \\
\hline Ether Extract & & $19.65^{b}$ & $18.05^{\mathrm{c}}$ & $17.23^{d}$ & $15.24^{\mathrm{e}}$ & $21.01^{\mathrm{a}}$ & 0.37 \\
\hline Moisture & & $8.01^{\mathrm{b}}$ & $9.01^{\mathrm{a}}$ & $2.83^{d}$ & $2.24^{\mathrm{e}}$ & $3.54^{c}$ & 0.52 \\
\hline Ash & & $7.45^{\mathrm{e}}$ & $10.02^{d}$ & $12.23^{b}$ & $13.01^{\mathrm{a}}$ & $11.01^{c}$ & 0.36 \\
\hline NFE & & $6.71^{\mathrm{d}}$ & $5.99^{e}$ & $6.87^{\circ}$ & $9.66^{\mathrm{a}}$ & $8.37^{b}$ & 0.25 \\
\hline
\end{tabular}

NFE: Nitrogen Free Extract, SEM: Standard Error of Means. a,b,c,d and e superscripts. Means with the same superscript in the same row are not significantly different $(P>0.05)$.
Table 6: Haematology of Juvenile African Catfish Fed Ginger Based Diets.

\begin{tabular}{|c|c|c|c|c|c|c|}
\hline Parameters & T1 & T2 & T3 & T4 & T5 & SEM \\
\hline PCV (\%) & $45.50^{\mathrm{ab}}$ & $40.00^{\mathrm{c}}$ & $43.50^{\mathrm{bc}}$ & $43.50^{\mathrm{bc}}$ & $48.00^{\mathrm{a}}$ & 0.65 \\
\hline WBC (cmm) & $12.00^{\mathrm{a}}$ & $9.25^{\mathrm{bc}}$ & $8.05^{\mathrm{cd}}$ & $7.60^{\mathrm{d}}$ & $10.00^{\mathrm{b}}$ & 0.31 \\
\hline HETERO (\%) & $35.00^{\mathrm{ab}}$ & $37.50^{\mathrm{a}}$ & $28.00^{\mathrm{cd}}$ & $31.50^{\mathrm{bc}}$ & $25.00^{\mathrm{d}}$ & 0.93 \\
\hline LYMPH (\%) & $29.00^{\mathrm{b}}$ & $46.00^{\mathrm{a}}$ & $51.50^{\mathrm{a}}$ & $52.50^{\mathrm{a}}$ & $46.50^{\mathrm{a}}$ & 0.57 \\
\hline NEUT (\%) & $1.50^{\mathrm{c}}$ & $1.50^{\mathrm{c}}$ & $1.00^{\mathrm{c}}$ & $2.50^{\mathrm{b}}$ & $3.50^{\mathrm{a}}$ & 0.17 \\
\hline BASO (\%) & $20.00^{\mathrm{a}}$ & $4.08^{\mathrm{c}}$ & $9.50^{\mathrm{b}}$ & $5.00^{\mathrm{c}}$ & $7.00^{\mathrm{bc}}$ & 0.92 \\
\hline BLAST (\%) & $14.50^{\mathrm{a}}$ & $11.00^{\mathrm{ab}}$ & $10.00^{\mathrm{b}}$ & $8.50^{\mathrm{b}}$ & $12.50^{\mathrm{ab}}$ & 0.62 \\
\hline Hb (gm/\%) & $15.10^{\mathrm{ab}}$ & $13.30^{\mathrm{c}}$ & $14.50^{\mathrm{bc}}$ & $14.50^{\mathrm{bc}}$ & $15.95^{\mathrm{a}}$ & 0.21 \\
\hline RBC (cmm) & $3.45^{\mathrm{cd}}$ & $3.33^{\mathrm{d}}$ & $3.70^{\mathrm{ab}}$ & $3.86^{\mathrm{a}}$ & $3.62^{\mathrm{bc}}$ & 0.04 \\
\hline MCV (FI) & $131.50^{\mathrm{b}}$ & $120.00^{\mathrm{b}}$ & $559.00^{\mathrm{a}}$ & $548.50^{\mathrm{a}}$ & $132.50^{\mathrm{b}}$ & 43.90 \\
\hline MCH (Pg) & $43.75^{\mathrm{a}}$ & $40.00^{\mathrm{ab}}$ & $39.85^{\mathrm{ab}}$ & $37.50^{\mathrm{b}}$ & $44.00^{\mathrm{a}}$ & 0.67 \\
\hline MCHC(g/dl) & $33.20^{\mathrm{b}}$ & $33.25^{\mathrm{ab}}$ & $33.35^{\mathrm{a}}$ & $33.30^{\mathrm{ab}}$ & $33.25^{\mathrm{ab}}$ & 0.02 \\
\hline
\end{tabular}

$a, b, c, d, e$ superscripts. Means in the same row with the same superscripts are not significantly different $(p>0.05)$. PCV: Packed Cell Volume, BLAST: Blast Cell (erythroblast, lymphoblast, neuroblast), WBC: White Blood Cell, Hb: Haemoglobin, HETERO: Heterophil, RBC: Red Blood Cell, LYMPH: Lymphocytes, MCV: Mean Corpuscular Volume, NEUT: Neutrophils, $\mathrm{MCH}$ : Mean Corpuscular Haemogblobin, BASO: Basophil, MCHC: Mean Corpuscular Haemoglobin Concentration

of $0.08 \mathrm{~g}\left(\mathrm{~T}_{5}\right)$ produced the highest $\mathrm{Hb}(15.95 \mathrm{gm} / \%)$ while that which was fed $0.02 \mathrm{~g}(\mathrm{~T} 2)$ produced the least $(13.30 \mathrm{gm} / \%)$ value. Highest values $(3.86 \%$ and $559.00 \mathrm{Fl})$ of $\mathrm{RBC}$ and MCV were observed in treatments four ( $\left.\mathrm{T}_{4}\right)$ and three $(\mathrm{T} 3)$ respectively, while the least values $(3.33 \%$ and $132.50 \mathrm{Fl})$ were observed in treatments two (T2) and five ( $\left.\mathrm{T}_{5}\right)$ respectively. Treatment five ( $\mathrm{T} 5)$ recorded the highest $(44.00 \mathrm{Pg}) \mathrm{MCH}$ while treatment four (T4) recorded the least value $(37.50 \mathrm{Pg})$. Treatments three (T3) and one $(\mathrm{T} 1)$ were recorded to have the highest $(33.35 \mathrm{~g} / \mathrm{dl})$ and least (33.20g/dl) MCHC respectively.

The serum biochemical indices of African catfish fed ginger based diets were presented in Table 7. All serum indices parameters were significantly different $(\mathrm{P}<0.05)$ except urea. It was revealed in Table 7 that highest ALP (19.50) was obtained in treatment 3 (T3) while the least ALP (14.62) was recorded in treatment 4 (T4). Highest AST (104.45) and ALT (28.91) was recorded in treatment 2 (T2) while the least AST (59.70) and ALT (18.45) is obtained in treatment 5 (T5). Highest ALB (14.04) was obtained in treatment 2(T2) while the least ALB (12.05) was recorded in treatment 5 ( $\left.\mathrm{T}_{5}\right)$. Highest TP (39.05) and GLOB (25.01) was recorded in treatment 2 (T2) while the lowest TP (34.19) and GLOB (20.81) was obtained in treatment 1 (T1). Highest CHOL (154.81) was recorded in treatment 5 (T5) while the least CHOL (126.99) was obtained in treatment 1 T1. Highest creatinine (0.35) was also recorded in both treatment 2 and 5 ( $\mathrm{T} 2$ and $\mathrm{T} 5$ ) while the least creatinine (0.18) was obtained in treatment $4(\mathrm{~T} 4)$.

\section{Sperm and eggs quality}

The sperm quality of juvenile African catfish fed ginger based diets in Table 8 recorded highest $\mathrm{pH}$ value (7.75) was obtained in $\mathrm{T} 1$ while the lowest (7.50) was recorded in all the other treatments ( $\mathrm{T} 2, \mathrm{~T} 3, \mathrm{~T} 4$ and $\mathrm{T} 5) . \mathrm{T} 1$ also has the highest volume $(4.50 \mathrm{ml}), \mathrm{T} 3$ and $\mathrm{T} 4$ has the lowest $(2.00 \mathrm{ml})$.

Citation: Olaniyi CO, Atoyebi MO, Obafunmiso HT, Salaam KA (2020) Effect of ginger (Zingiber officinale) in the nutrition of african catfish-A cholesterol reducer and fertility enhancer. Int J Aquac Fish Sci 6(2): 021-028. DOI: https://dx.doi.org/10.17352/2455-8400.000052 
Spermatocrit highest rate $(44.00 \%)$ was recorded in T1 while the least $(27.50 \%)$ was obtained in $\mathrm{T} 4$. Sperm motility is highest $(67.50 \%)$ in $\mathrm{T}_{5}$ and lowest $(45.00 \%)$ in $\mathrm{T}_{4}$. Highest sperm density(267.50) is obtained in $\mathrm{T}_{5}$ while the lowest (190.50) is T3 .Sperm alive is highest (180.85) in T5 and lowest in T3(114.30) while sperm dead is highest(135.90) in T3 and lowest(79.35) in T2.

The egg quality of juvenile African catfish fed ginger based diets in Table 9, revealed that for parameters ( volume, weight and number ) $\mathrm{T}_{5}$ has the highest value $(40.00 \mathrm{ml}, 36.50 \mathrm{~g}$ ,25600) respectively while for parameters (volume, weight, number) $\mathrm{T} 1$ has the least value $(25.00 \mathrm{ml}, 24.00 \mathrm{~g}$ and 16800$)$ respectively

\section{Discussion}

Medicinal plants have been reported to be growth promoters and immune boosters in livestock and fish nutrition $[6,16$ 18]. The findings of the present study on growth performance of Clarias gariepinus juvenile fed ginger supplemented diets revealed that there was an increase in all the treatments for all parameters, as compared to the control. There was a significant increase in the final weight and weight gain of fish

Table 7: Serum Biochemical Indices of Juvenile African Catfish Fed Varying Levels of Ginger Based Diets.

\begin{tabular}{|c|c|c|c|c|c|c|}
\hline Parameters & $\begin{array}{c}\text { T1 } \\
(\mathbf{0})\end{array}$ & $\begin{array}{c}\text { T2 } \\
\mathbf{( 5 \% )}\end{array}$ & $\begin{array}{c}\text { T3 } \\
(\mathbf{1 0 \% )}\end{array}$ & $\begin{array}{c}\text { T4 } \\
(\mathbf{1 5 \% )}\end{array}$ & $\begin{array}{c}\text { T5 } \\
(\mathbf{2 0} \%)\end{array}$ & SEM \\
\hline ALP(u/l) & $15.69^{\mathrm{ab}}$ & $17.44^{\mathrm{ab}}$ & $19.50^{\mathrm{a}}$ & $14.62^{\mathrm{b}}$ & $18.06^{\mathrm{ab}}$ & 0.63 \\
\hline AST(u/l) & $68.93^{\mathrm{c}}$ & $104.45^{\mathrm{a}}$ & $91.78^{\mathrm{b}}$ & $67.73^{\mathrm{c}}$ & $59.70^{\mathrm{c}}$ & 2.90 \\
\hline ALT(u/l) & $23.52^{\mathrm{bc}}$ & $28.91^{\mathrm{a}}$ & $25.75^{\mathrm{b}}$ & $22.36^{\mathrm{c}}$ & $18.45^{\mathrm{d}}$ & 0.57 \\
\hline TP(g/l) & $34.19^{\mathrm{c}}$ & $39.05^{\mathrm{a}}$ & $36.81^{\mathrm{b}}$ & $34.66^{\mathrm{bc}}$ & $36.34^{\mathrm{bc}}$ & 0.39 \\
\hline ALB(g/l) & $13.38^{\mathrm{ab}}$ & $14.04^{\mathrm{a}}$ & $12.07^{\mathrm{c}}$ & $12.74^{\mathrm{bc}}$ & $12.05^{\mathrm{c}}$ & 0.20 \\
\hline GLOB(g/l) & $20.81^{\mathrm{b}}$ & $25.01^{\mathrm{a}}$ & $24.74^{\mathrm{a}}$ & $21.42^{\mathrm{b}}$ & $24.29^{\mathrm{a}}$ & 0.44 \\
\hline CHOL(mg/dl) & $126.99^{\mathrm{b}}$ & $133.34^{\mathrm{b}}$ & $130.16^{\mathrm{b}}$ & $151.59^{\mathrm{a}}$ & $154.81^{\mathrm{a}}$ & 2.51 \\
\hline UREA(mg/dl) & 14.95 & $15.12^{2}$ & 15.12 & 15.12 & 15.21 & 0.11 \\
\hline CREATININE(mg/dl) & $0.20^{\mathrm{c}}$ & $0.35^{\mathrm{a}}$ & $0.27^{\mathrm{b}}$ & $0.18^{\mathrm{c}}$ & $0.35^{\mathrm{a}}$ & 0.01 \\
\hline
\end{tabular}

$a, b, c, d, e-$ superscripts. Means in the same row with the same superscripts are not significantly different $(p>0.05)$

ALP: Alkaline phosphate; AST: Aspartate transaminase; ALT: Alanine transaminase; ALB: Albumin; GLOB: Globulin; CHOL: Cholesterol; TP: Total protein; UREA, CREATININE.

Table 8: Sperm Quality of Juvenile African Catfish Fed Ginger Based Diets.

\begin{tabular}{|c|c|c|c|c|c|c|}
\hline Parameters & T1(control) & T2(5\%) & T3(10\%) & T4(15\%) & T5(20\%) & SEM \\
\hline Vol( ml) & $4.50^{\mathrm{a}}$ & $3.50^{\mathrm{c}}$ & $2.00^{\mathrm{d}}$ & $2.00^{\mathrm{d}}$ & $4.00^{\mathrm{b}}$ & 0.15 \\
\hline $\mathrm{Ph}$ & $7.75^{\mathrm{a}}$ & $7.50^{\mathrm{b}}$ & $7.50^{\mathrm{b}}$ & $7.50^{\mathrm{b}}$ & $7.50^{\mathrm{b}}$ & 0.36 \\
\hline Spermatocrit(\%) & 44.00 & 38.50 & 40.00 & 40.00 & 42.50 & 1.28 \\
\hline Motility (\%) & $62.50^{\mathrm{b}}$ & $62.50^{\mathrm{b}}$ & $60.00^{\mathrm{b}}$ & $45.00^{\mathrm{c}}$ & $67.50^{\mathrm{a}}$ & 1.14 \\
\hline Sperm Density & $236.00^{\mathrm{b}}$ & $213.00^{\mathrm{c}}$ & $190.50^{\mathrm{d}}$ & $200.50^{\mathrm{cd}}$ & $267.50^{\mathrm{a}}$ & 4.31 \\
\hline Sperm Alive & $147.67^{\mathrm{b}}$ & $133.65^{\mathrm{b}}$ & $114.30^{\mathrm{c}}$ & $92.05^{\mathrm{d}}$ & $180.85^{\mathrm{a}}$ & 4.52 \\
\hline Sperm Dead & $88.65^{\mathrm{bc}}$ & $79.35^{\mathrm{c}}$ & $135.90^{\mathrm{a}}$ & $108.45^{\mathrm{b}}$ & $86.65^{\mathrm{bc}}$ & 4.65 \\
\hline
\end{tabular}

$a, b, c, d$ and e superscripts. Means with the same superscript in the same row are not significantly different $(P>0.05)$. Vol: Volume
Table 9: Egg Quality of Juvenile African catfish fed Ginger Meal.

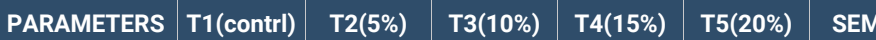

\begin{tabular}{|l|l|l|l|l|l|l|}
\hline EggsVol. (ml) & $25.00^{\mathrm{b}}$ & $30.00^{\mathrm{b}}$ & $40.00^{\mathrm{a}}$ & $40.00^{\mathrm{a}}$ & $40.00^{\mathrm{a}}$ & 1.33 \\
\hline
\end{tabular}

\begin{tabular}{|l|l|l|l|l|l|l|}
\hline Eggs Weight (g) & $24.00^{\mathrm{b}}$ & $30.50^{\mathrm{a}}$ & $35.00^{\mathrm{a}}$ & $35.50^{\mathrm{a}}$ & $36.50^{\mathrm{a}}$ & 1.10
\end{tabular}

\begin{tabular}{ll|l|l|l|l|l|} 
Eggs Number & $16800.00^{\mathrm{b}}$ & $21350.00^{\mathrm{a}}$ & $24500.00^{\mathrm{a}}$ & $24850.00^{\mathrm{a}}$ & $25600.00^{\mathrm{a}}$ & 767.60
\end{tabular}

$a, b, c, d$ and e superscripts. Means with the same superscript in the same row are not significantly different $(P>0.05)$.

fed $15 \%$ inclusion of ginger than the fish fed the control diet. The same trend was observed for the ADWG, PWG, TFT, SGR, PI and PER. The present study agrees with Iheanacho, et al. [18], who reported significant increase in weight gain(WG), specific growth rate (SGR) and final weight (FW) when C.gariepinus juvenile were exposed to varying concentrations $(0.25,0.50$, 0.75 and $1.0 \mathrm{~g} / 35 \mathrm{~L}$ ) of ginger as compared to the control. The high proximate content of ginger may be an influence on the positive response to growth in treated fish, especially at $15 \%$ inclusion level of ginger which has the best response in all the parameters.

Carcass composition was significantly affected by intake of ginger. Moisture content increased with increase in ginger inclusion levels and was least value of $2.24 \%$ was found in T4. This agreed with the findings of Ali, et al. [19]. This could be attributed to corresponding decrease in the energy level of diets. Fanullah and Jafri [20], reported a strong inverse relationship between moisture content of fish and the energy level of their diets. The Ash content of fish fed the inclusion level of ginger were significantly different $(\mathrm{p}<0.05)$. The highest was recorded in $\mathrm{T} 4$ (15\% inclusion level of ginger) while the lowest value (7.45) was obtained in T1. Crude fibre was high in $\mathrm{T} 33$ and this might be as a result of low ash and crude fibre content of the tested ingredient (ginger) as was also observed by Erdal, et al., [21]. Crude protein of fish decreased with increase in ginger inclusion and recorded the highest in T4. This enhanced the crude protein content of $C$. gariepinus.

Blood is a vital special circulatory tissue, composed of cells suspended in a fluid intercellular substance (plasma) with the major function of maintaining homeostasis [22]. Packed Cell Volume (PCV), also known as haematocrit(Ht or Hct) or erythrocyte volume fraction (EVF), is the percentage of red blood cells in blood [23] and is involved in the transport of oxygen and absorbed nutrients [22]. In this present study PVC values increased from initial value of $45.50 \%$ in fish fed the control diet $\left(\mathrm{T}_{1}\right)$ to final value of $48.00 \%$ in fish fed $1.6 \mathrm{~g}$ ginger diet $\left(\mathrm{T}_{5}\right)$ which contradicts Korzhuev (1964) [23] who stated that fish haematocrit values ranged between $20 \%$ and $35 \%$. The results obtained falls within the range of $20 \%$ and $50 \%$ in agreement with Etim, et al. [24], who also stated that PCV values above $50 \%$ are rarely reported. Increased PCV results to an increased primary and secondary polycythemia [22], however, Sotolu and Faturoti [25] reported that lower PCV values is attributed to anaemia, thus the present study reveals that there is no tendency for anaemia.

Red blood cell is involved in the transport of oxygen carried to the tissues and carbondioxide returned to the lungs in the body $[22,26,27]$. The red blood cell $\left(\mathrm{RBC}_{\mathrm{s}}\right)$ increased from the 
initial value of $3.45 \%$ in the fish fed control diet (T1) to the final value of $3.86 \%$ in fish fed $15 \%$ ginger diet (T4). These values were higher than $1.9 \times 10^{12} \mathrm{~L}^{-1}$ reported for Clarias gariepinus juveniles [28].

The final white blood cell counts (WBC) of C.gariepinus juveniles fed ginger included diets ranged between $7.60 \mathrm{cmm}$ in fish fed $15 \%$ ginger based diet (T4) and $10.00 \mathrm{cmm}$ in fish fed $20 \%$ ginger-based diets $(\mathrm{T})$ and were generally lower and significantly different from the initial WBC count $(12.00 \mathrm{cmm}$; $\mathrm{T}_{1}$ ). [29] stated that increasing or decreasing numbers of $\mathrm{WBC}_{\mathrm{s}}$ are normal physiological reactions to toxicants and these shows the response of the immune system under toxic conditions. However, Soetan, et al., 2013 [30], stated that animals with low white blood cells are exposed to high risk of disease infections while those with high counts are capable of generating antibodies in the process of phagocytocis and have high degree of resistance to diseases. They also have high degree of resistance to entrance adaptability to local environmental and disease prevalent conditions [22,31-33].

Mean corpuscular volume (MCV) indicates the status or size of the RBCs and reflects a normal or an abnormal cell division during the production of $\mathrm{RBC}$. The result gotten from the present study showed that fish fed with $10 \%$ ginger diet $\left(T_{3}\right)$, gave the highest volume $(559.00 \mathrm{Fl})$ while the fish fed $5 \%$ ginger diet $\left(\mathrm{T}_{2}\right)$, had the least $(120.00 \mathrm{Fl}) \mathrm{MCV}$ value. These values are higher when compared to $79.20-105.32 \mu \mathrm{g} / \mathrm{ml}$ reported for Heteroclarias [34]. This increase may be attributed to the swelling of the RBCs as a result of low oxygen condition and impaired water balance in fishes exposed to metal pollution [35].

Mean corpuscular haemoglobin $(\mathrm{MCH})$ values were significantly different. The highest value $(44.00 \mathrm{Pg})$ was recorded in fish fed $20 \%$ ginger based diet ( $\left.\mathrm{T}_{5}\right)$ while the least $(37.50 \mathrm{Pg})$ was recorded in fish fed $15 \%$ ginger based diet $\left(\mathrm{T}_{4}\right)$. These values agrees with Olasunkanmi [36] who reported a significant increase in the final $\mathrm{MCH}$ values in $C$. gariepinus fed raw mucuna seed meal-based diets.

The values recorded for mean corpuscular haemoglobin concentration (MCHC) (33.20g/dl, 33.25g/dl, 33.25g/dl, 33.30g/ $\mathrm{dl}$ and $33.35 \mathrm{~g} / \mathrm{dl}$ ) compares fairly well with $33.97 \%$ recorded by Adeyemo, (2007)[37] and values ranging between 28.75 and $37.62 \%$ recorded for fish fed M.Oleifera leaf meal-based diet [38].

\section{Serum biochemical indices}

In fish, proteins are among the main energy sources which play an important role in the maintenance of blood glucose [39]. The observed increase in the total protein content of fish in the study fed diet containing $0.02 \mathrm{~g}$ of ginger could be linked with the level of anti-nutrients present in the diets. Yadav, et al. 2003 [40], who also reported a decrease in serum total protein content in Channa punctatus induced with stem-bark extract of Croton tiglium. Decrease in total protein in the fish fed control diet maybe exposed to toxic levels of toxicants which could be attributed to either a state of hydration and change in water equilibrium in the fish or a disturbance in protein synthesis within the liver or both [41].

The slight decrease of serum albumin in the study which can be observed in fishes fed $0.04 \mathrm{~g}$ and $0.08 \mathrm{~g}$ of ginger diet might be due to their degradation and utilization for metabolic purposes. The higher values of ALT in the study(5\% ginger) may occur due to the blood serum enzyme in the experimental fish efficiently utilized amino acids for metabolic purposes, confirming the observation of Adesina [42]. Transaminases are important enzymes for monitoring the health status of fish [43] and leak out into the bloodstream from dying or damaged liver cells. Increased levels of transaminases in the blood serum of fish are usually associated with dying or damaged liver cells while a decrease could suggest leakage of enzymes into the serum $[1,44]$, which is observed in the study. Increased level of AST in the study which is observed in $15 \%$ ginger might be due to stress or due to increased levels of anti-nutrients at higher inclusion.

It increase in response to stress [45] and this can be observed in the study. The lower AST values recorded in fish fed control and $15 \%$ ginger based diets corroborated the report of [46] that there was inhibition of AST and ALT activities in the liver of catfish after intoxication with dietary ochratoxin. The observation also agreed with that of Dienye and Olumuji, et al. 2014 [38], who reported elevated ALT, AST and ALP. Activities in fish fed $30 \% \mathrm{M}$. Olefera leaf meal diet and above which suggested hepatic cellular damage leading to their leakage into the bloodstream [47]. This is also similar to [48], who reported that increase in serum protein, albumin and globulin level maybe as a result of immune response to certain constituents of the extracts which can be observed in the study. Khahil, et al. [49], also reported that ginger when administered as bath treatment significantly decreased both ALT and creatinine levels in serum of Clarias gariepinus infested with gill monogenia, Bello, et al. [50], also reported that the decrease observed in ALT, ALP and ALB activities might be attributed to stress induced during fish sampling for blood collection, capturing and handling procedure

The increased sperm motility, sperm density and sperm alive after 12 weeks of treatment with $20 \%$ inclusion revealed that with ginger powder boosts the fertilizing ability of semen. A study of male rats on effects of ginger on reproductive functions proved that ginger enhanced fertility in male especially in sperm characteristics which might be as a result of potentability of antioxidant and androgenic properties. In this study, sperm $\mathrm{pH}$ is slightly above neutral across all the treatments with the fishes fed the control diet having the highest $\mathrm{pH}$ value (7.75) while $\mathrm{pH}$ values were uniform (7.50) in all other treatments. The milt volume decreased as inclusion levels increased, the fishes fed the control meal recorded the highest value $(4.50 \mathrm{ml})$ and the lowest $(2.00 \mathrm{ml})$ in fishes fed $10 \%$ (treatment 3 ) and $15 \%$ (treatment 4 ) of ginger meal, this disagrees with the findings of Dada and Ogundiyile [49] on the effect of velvet beans on sperm quality on African catfish who observed that milt volume increased as inclusion levels increased having its highest value $(0.91 \mathrm{ml})$ in $\mathrm{D} 5$ and lowest 
(0.59ml) in the fishes fed the control diet. It was also recorded that there was significant difference in the spermatocrit of all treatments, the fishes fed the control diet obtained the highest value $(44 \%)$, while the least rate $(27.50 \%)$ was obtained in the fishes fed $15 \%$ of ginger meal.

This study revealed that egg volume, weight and number $(40 \mathrm{ml}, 36.50 \mathrm{~g}, 25600)$ respectively were significantly increased in fishes fed ginger diet inclusion at $20 \%$ (treatment 5). This is in agreement with Cek and Yilmaz [51], who reported that the number of eggs is determined based on its weight, the relationship between egg weight and number is also observed in this study. The result obtained from this study also agrees with the findings of Zhao, et al. [11], on the effect of ginger powder on laying performance of laying hens who recorded that egg mass was quadratically increased by ginger powder supplementation at levels up to $20 \mathrm{~g} / \mathrm{kg}$ of diet .This study suggests that ginger has a favourable effect on egg quality of African catfish (volume, number and weight).Furthermore, the increased egg quality shows that treatment with ginger powder improves and enhanced rate of fertilization in eggs.

\section{Conclusion}

The result obtained in this study revealed that, inclusion of $15 \%$ ginger (treatment 4 ) in the diet of African catfish generally increased the growth optimally and reduced the serum biochemical indices to the minimal level required by the fish Although, ginger inclusion as high as $20 \%$ enhances carcass, egg quality and sperm fertility. However, it can be concluded that $15 \%$ ginger based diet can be included in the diet of African catfish to enhance a better performance.

\section{Recommendation}

$15 \%$ of ginger inclusion in the diet of African catfish is therefore recommended for growth, good carcass quality as well as boosting reproduction (milt and egg) without health deterioration

\section{References}

1. Ozovehe BM (2013) Growth performance, haematological indices and some biological enzymes of juvenile Clarias gariepinus (Burchell 1822) fed varying levels of Moringa oleifera meal diet. J Aquac Res Development 4: 1-6. Link: https://bit.ly/2Z3xcwX

2. FAO (2008) Traditional Food Plants. Food and Agricultural Organization (FAO/ UN), Rome. Food and Nutrition Paper 42.

3. Ashraf MA, Maah M, Yusoff I (2011) Assessment of heavy metals in the fish samples of mined out ponds estari Jaya, Peninsular Malaysia. Proc Indian Nat Sci Acad 77: 57-67. Link: https://bit.ly/2SOkOwL

4. Fafioye OO, Oluajo OA (2005) Length- weight relationships of five fish species in Epe lagoon, Nigeria. Afr $\mathrm{J}$ Biotechnol 4: 749-751. Link: https://bit.ly/2WnZQHk

5. Adewumi AA, Olaleye VF (2010) Catfish culture in Nigeria; Progress, prospects and problem.University of Science and Technology Ifaki-Ekiti, Nigeria. Afr J Agric Res 6: 1281-128. Link: https://bit.ly/3fDfciF

6. Levic JG, Sinisia MG, Djuragic O, Slavica S (2008) organic acids as alternative to antibioticgrowth promoter. Archina Zootechnica 11: 15-1.
7. Alector VA, Osho IB (2009) Formulation of medicinal plants for animal production. Invited paper II. Proceedings of the Humbolt kellog $5^{\text {th }}$ Annual Agriculture Conference on formulation of medicinal plants for crop and animal production in Nigeria. Realities and Challenges. Federal University of Technology, Akure 718

8. Okwuowulu PA (1997) Ginger (Zingber officinale): An update in its production and challenges for the future. African Journal of Root and Tuber Crops 3: 7- 11

9. Stoilova I, Krastanov A, Stoyanova A, Denev P, Gargova S (2007) Antioxidant activity of a ginger extract (Zingiber officinale) Food chemistry 102: 764-770. Link: https://bit.ly/2WNBDsT

10. Martins EA, Chubatsu LS, Meneghini R (1991) Role of antioxidants in protecting cellular DNA from damage by oxidative stress. Mutat Res 250: 95-101. Link: https://bit.ly/3craBOw

11. Hosseini J, Mamaghani AM, Hosseinifar H, Gilani MAS, Dadkhah F, et al. (2016) The influence of ginger (Zingiber officinale) on human sperm quality and DNA fragmentation: A double blind randomized clinical trait. Int J Reprod Biomed 14: 533-540. Link: https://bit.ly/3fEPLNN

12. Zhao X, Yang ZB, Yang WR, Wang Y, Jiang SZ, et al. (2011) Effects of ginger root (Zingiberofficinale) on laying performance and antioxidant status of laying hens and on dietary oxidation stability. Poult Sci 90: 1720-1727. Link: https://bit.ly/3fECzsc

13. Nya EJ, Austin B (2009) Use of ginger Roscoe as an immunostimulant to control Aeromonas hydophilia infection in rainbow trout Oncorhynchus mykiss (Walbaum). J Fish Dis 32: 971-977. Link: https://bit.ly/2YR7RpH

14. Tan BK, Vanitha J (2004) Immunomodulatory and antimicrobial effect of some traditional Chinese medicinal herbs: a review. Curr Med Chem 11: 1423 1430. Link: https://bit.ly/2WL8sGL

15. AOAC (2000) Association of Official Analytical Chemists international (AOAC) Official methods of analysis, $17^{\text {th }}$ edition AOAC International, Gaithersburg, MD, USA.

16. Kumar G, Engle CR (2014) Optimizing catfish feeding and stocking strategies over a two-year planning horizon. Aquaculture Economics and Management 18: 169-188. Link: https://bit.ly/2LklbuG

17. Reverter M, Bontemps N, Lecchini D, Banaigs B, Sasal P (2014) Use of plant extracts in fish aquaculture as an alternative to chemotherapy: current status and future perspectives, Aquaculture 433: 50-61. Link: https://bit.ly/3cnjZ5F

18. Iheanacho SC, Ogueji EO, Nwuba LA, Nnatuanya IO, Ochang SN, et al. (2017) Comparative assessment of ampicillin antibiotic and ginger (Zingiber officinale) effects on growth, haematology and biochemical enzymes of Clarias gariepinus juvenile. J Pharmacog Phytochem 6: 761-767. Link: https://bit.ly/2SWktrX

19. Ali BA, Blunden G, Tanira MO, Nemmar A (2008) Some pharmacological and toxicological properties of ginger (Zingiber officinale Roscoe): A review of recent research. Food Chem Toxicol 46: 409-420. Link: https://bit.ly/2LisXW2

20. Fanullah ER, Jafri AK (1998) Growth response, feed utilization and nutrient retention in Catlacatla (Ham) fry fed varying levels of dietary carbohydrate. Asian Fisheries Science 11: 223-230.

21. Erdal Y, Mehmet N, Ihsan A (2004) Effect of dietary olive pomance oil and L-carnitine on growth and chemical composition of African catfish, Clarias gariepinus (Burchell, 1822). The Israel journal of Aquaculture-BAMIGDEH 56 14-21. Link: https://bit.ly/3dC3xi2

22. Isaac LJ, Abah G, Akpan B, Ekaette IU (2013) Haematological properties of different breeds and sexes of rabbits. Proceedings of the $18^{\text {th }}$ Annual Conference of Animal Science Association of Nigeria 24-27. Link: https://bit.ly/3dCD6sW

23. Korzhuev PA (1964) Methods of study of blood in fish. Techniques for the investigation of Fish physiology 2-10

Citation: Olaniyi CO, Atoyebi MO, Obafunmiso HT, Salaam KA (2020) Effect of ginger (Zingiber officinale) in the nutrition of african catfish-A cholesterol reducer and fertility enhancer. Int J Aquac Fish Sci 6(2): 021-028. DOI: https://dx.doi.org/10.17352/2455-8400.000052 
24. Purves K, David Sadava, GordonOrians, H, Craig Heller H (2003) Life: the science of biology: ( $7^{\text {th }}$ edition): plants and animals. Macmillan 1121

25. Etim L, Ekanem SB, andUtin A (1999) Haematologicalprooflie of two species of catfish, Chrysichthysnigrodigitatus (Lacepede) and Chrysichthysfurcatus (Gunther) from the Great Kwa River, Nigeria. Global Journal of Pure and Applied Sciences 5: 1-4.

26. Sotolu AO, Faturoti EO (2011) Digestibility and Nutritional Values of Differently Processed Leucaenaleucocephala (Lam De Wit) Seed Meals in the Diet of African catfish (Clariasgariepinus). Middle East Journal of Scientific Research 3: 190-199.

27. Ugwuene MC (2011) Effect of dietary palm kernel meal for maize on the haematological and serum chemistry of broiler turkey. Nigerian J Anim Sci 13 93-103. Link: https://bit.ly/2WmLM0o

28. Soetan KO, Akinrinde AS, Ajibade TO (2013) Preliminary studies on the haematological parameters of cockerels fed raw and processed guinea corn (Sorghum bicolor). Proceedings of $38^{\text {th }}$ Annual Conference of Nigerian Society for Animal Production 49-52.

29. Ayoola OS (2011) Haematological characteristics of Clariasgariepinus (Buchell,1822) juveniles fed with poultry hatchery waste. Iranica Journal of energy and environment 2: 18-23. Link: https://bit.ly/2Lk6VIC

30. Alkahem HF, Ahmed Z, Al-Akel AS, Shamsi MJK (1998) Toxicity bioassay and changes in haematological parameters of Oreochromisniloticusinduced by trichlorfon. Arab Gulf Journal of Scientific Research 16: 581-593. Link: https://bit.ly/35QP9jj

31. Kabir M, Akpa GN, Nwagu BI, Adeyinka IA, Bello UI (2011) Sexual dimorphism, breed and age characteristics of rabbits in Zaria, Nigeria. Proceedings of the $16^{\text {th }}$ Annual Conference of Animal Science Association of Nigeria 133-137.

32. Okunlola DO, Olorunisomo AO, Aderinola AO, Agboola AS, Omole OG (2012) Haematology and serum quality of red Sokoto goats fed Baobab (Adansoniadigitata) fruit meal as supplement to guinea grass (Panicum maximum). Proceedings of the 17th Annual Conference of Animal Science Association of Nigeria 427-433.

33. Iwuji TC, Herbert U (2012) Haematological and serum biochemical characteristics of rabbit bucks fed diets containing garcimiola kola seed meal. Proceedings of $37^{\text {th }}$ Annual conference of nigerian society for animal production 87-89.

34. Anyanwu DC, Udedibie ABI, Osuigwe DI, Ogwo VO (2011) Haematologicalresponse ofhybrid of Heterobranchusbidorsalis and Clariasgariepinus fed dietarylevels of Caricapapaya leaf meal. World Rural Observation 3: 9-12

35. Larsson A, Haux C, Sjöbeck ML (1985) Fish physiology and metal pollution:Results and experiences from laboratory and field studies. Ecotoxicol Environ Saf 9: 250-281. Link: https://bit.ly/3co5pLc

36. Olasunkanmi JB (2011) Nutrient utilisation and growth performance of Clariasgariepinus fed differently processed Mucunautilis meals as a replacement for soybean baseddiet. PhD. Thesis, University of Ibadan, Ibadan, Nigeria 209. Link: https://bit.ly/3bjc5ZL

37. Adeyemo OK (2007) Haematological profile of Clariasgariepinus (Burchell,1822) exposed to lead. Turkish Journal of Fisheries and Aquatic Sciences 7:163-169. Link: https://bit.ly/2yNo1pn
38. Dienye HE, Olumuji OK (2014) Growth performance and haematologica responses of African mud catfish Clariasgariepinus fed dietary levels of Moringaoleifera leaf meal. Net J Agric Sci 2: 79-88. Link: https://bit.ly/2SUhZKs

39. Shwetha A, Hosetti BB, Dube PN (2012) Toxic effects of zinc cyanide on some protein metabolites in freshwater fish, Cirrhinus mrigala (Hamilton). Int $J$ Environ Res 6: 769-778. Link: https://bit.ly/2SSIJLy

40. Yadav RP, Singh D, Singh SK, Singh A (2003) Metabolic changes in freshwater fish Channa punctatus due to stem-bark extract of Crotontiglium. Pak J Biol Sci 6: 1223-1228. Link: https://bit.ly/350YNTD

41. Gluth G, Hanke W (1984) A Comparison of physiological changes in carp (Cyprinus carpio) induced by several pollutants at sublethal concentration II the dependency on the temperature. Comp Biochem Physiol C 79: 39-45. Link: https://bit.ly/2zoGhph

42. Adesina BT (2008) Toxicity of Moringa Oleifera (Lam) Extracts to Oreochromis niloticus Fingerlings and Juveniles. PhD. Thesis. University of Ibadan. 261.

43. Racicot JG, Gaudet M, Leray C (1975) Blood and liver enzymes in rainbow trout (Salmo gairdneri Rich.) with emphasis on their diagnostic use: Study of CC14 toxicity and a case of Aeromonas infection. J Fish Biol 7: 825-835. Link: https://bit.ly/3dwSpDg

44. Yilmaz E, Genc MA, Cek S, Mazlum Y, Genc E (2006) Effects of orally administereFerula coskunii (Apiaceae) on growth, body composition and histology of common carp, Cyprinus carpio. Journal of Animal and Veterinary Advances 5: 1236-1238.

45. Tiwari DP, Singh M, Kumar A, Kumar MR (2003) Effect of feeding transgenic cottonseed vis-avis non-transgenic cottonseed on haematobiochemical constituents in lactating Murrah buffaloes. Asian-Australas J Anim Sci 16 1732-1737. Link: https://bit.ly/2YMVICe

46. Mousa MA, Khattab YA (2003) The counteracting effect of Vitamin C (L-ascorbic acid) on the physiological perturbations induced by ochratoxin intoxication in African catfish (Clarias gariepinus). Journal of Egypt Academy and Environmental Development 4: 117-128.

47. Mousa MMA, El-Ashram AMM, Hamed M (2008) Effects of Neem lea extract on freshwater fishes and zooplankton community.8th International Symposium on Tilapia in Aquaculture. The Central Laboratory for Aquaculture Research, Cairo, Egypt. 12-14. Link: https://bit.ly/2WMJSoO

48. Wiegertjes GF, Stet RJM, Parmentier HK, Vas Muiswinkel WB (1996) Immunogenetics of disease resistance in fish: a comparable approach. Dev Comp Immunol 20: 357-64. Link: https://bit.ly/2zrZHJI

49. Khalil FF, Mehrim Al, Hassan MEM (2013) Effect of Hydroyeast Aquaculture as growth promoter for adult Nile tilapia Oreochromis niloticus. Engormix.com 10. Link: https://bit.ly/3fDkWZL

50. Bello OS, Olaifa FE, Emikpe BO (2014) Haematological and blood biochemical changes in African catfish, Clarias gariepinus fed walnut (Tetracarpidum conophirum) leaf and onion (Allium cepa linn) bulb supplemented diets. American journal of Experimental Agriculture 4: 1593-1603. Link: https://bit.ly/2xVLEv

51. Dada AA, Ogunduyile FD (2011) Effects of velvet bean (Mucuna puriens) on sperm quality of African Catfish, Clarias gariepinus (Burchell, 1822) broodstock. Journal of Fisheries and Aquatic Science 6: 655-661.

Copyright: @ 2020 Olaniyi CO, et al. This is an open-access article distributed under the terms of the Creative Commons Attribution License, which permits unrestricted use distribution, and reproduction in any medium, provided the original author and source are credited.

Citation: Olaniyi CO, Atoyebi MO, Obafunmiso HT, Salaam KA (2020) Effect of ginger (Zingiber officinale) in the nutrition of african catfish-A cholesterol reducer and fertility enhancer. Int J Aquac Fish Sci 6(2): 021-028. DOI: https://dx.doi.org/10.17352/2455-8400.000052 